\title{
Hormonal regulation of lysosomal hydrolases in the reproductive tract of the rabbit*
}

\author{
H. Rahi and P. N. Srivastava \\ Department of Biochemistry, University of Georgia, Athens, Georgia 30602, U.S.A.
}

\begin{abstract}
Summary. The total protein content and the activities of lysosomal hydrolases (arylsulphatase, alkaline and acid phosphatases, $\beta$-glucuronidase, $\beta$ - $N$-acetylhexosaminidase, $\alpha$-L-fucosidase and $\beta$-galactosidase) in the uteri of ovariectomized rabbits treated with different concentrations of progesterone, oestradiol- $17 \beta$ and a combination of progesterone and oestradiol were determined. The enzyme activities were also measured in the reproductive organs of rabbits induced to superovulate by PMSG and hCG. In superovulated and steroid-treated rabbits, the changes in lysosomal hydrolases were more obvious in the endometrium than the myometrium. Except for the myometrial alkaline phosphatase and $\beta$-galactosidase and the endometrial alkaline phosphatase, there were no significant changes in the solubilities of hydrolases after treatment with steroids. $\beta$-Galactosidase levels were significantly higher in the ovariectomized rabbits treated with progesterone. An antagonistic effect of oestradiol and progesterone was observed with respect to uterine weight, protein content and enzyme activities in the ovariectomized rabbits treated simultaneously with oestradiol and progesterone.
\end{abstract}

\section{Introduction}

Removal of the ovaries or corpora lutea from rabbits interrupts capacitation (Soupart, 1967; Plotka \& Williams, 1971), implantation and pregnancy (Allen \& Corner, 1929). Administration of exogenous hormones restores capacitation (Soupart, 1967; Hamner, Jones \& Sojka, 1968; Chang, 1970; Plotka \& Williams, 1971), implantation and the maintenance of pregnancy (Pincus \& Werthessen, 1938; Kwun \& Emmens, 1975), but the amount and type of exogenous hormones are crucial.

Some of the effects of steroid hormones on target cells seem to be mediated through the synthesis of specific proteins. Oestrogen-induced proteins (Kaye \& Reiss, 1980) and many other proteins are known to be specific to the reproductive tract in various mammalian species (Aitken, 1977; Surani, 1977; Shalgi, Kaplan \& Kraicer, 1977). The steroid sex hormones also exert their effect on target organs through enzymic processes (Laidler \& Krupka, 1961), particularly those involving the lysosomal hydrolases (Szego, 1974; Sloane, 1980). The steroid effects may be mediated through lysosomes by changing their permeability (Weissman, 1965), fragility, subcellular distribution (Szego \& Seeler, 1973; Szego, 1974) and/or by increasing the rate of release of lysosomal enzymes (deDuve, Wattiaux \& Wibo, 1963). It is believed that lysosomal hydrolases play a part in several important processes of reproduction, such as tissue regression (Dott, 1973), ovulation (Dimino \& Elfont, 1980), capacitation (Gwatkin \& Hutchinson, 1971), acrosome reaction (McRorie \& Williams, 1974), implantation and early pregnancy (Denker, Eng \& Hamner, 1978; Moulton, Koenig \& Borkan, 1978). Several workers have demonstrated the hormonal regulation of lysosomal hydrolases in the reproductive system (Hall \& Khaligh, 1968; Henzl, Smith, Boost \&

* Reprint requests to Dr P. N. Srivastava. 
Tyler, 1972; Jelinek \& Jelinkova, 1975; Murdoch, Kay \& Cross, 1978; Findlay et al., 1981). However, little is known of the hormonal effects on the latency and the solubility of lysosomal hydrolases in the female reproductive tract (Dimino, Malcom \& Elfont, 1977; Rosado, Mercado \& Gallegor, 1977). This paper describes comprehensive studies on the solubility and distribution of lysosomal hydrolases in uterine tissues of rabbits treated with various hormones.

\section{Materials and Methods}

Materials. Substrates for the enzyme assays, hCG, oestradiol benzoate and progesterone were obtained from Sigma Chemical Co., St Louis, Missouri. PMSG (Gestyl) was from Organon, Inc., New Jersey. Hyamine 2389 and Triton X-100 were from Rohm and Hass Co., Philadelphia, Pennsylvania. Other chemicals were of analytical purity.

Steroid treatment. Mature, female New Zealand white rabbits were bilaterally ovariectomized via mid-ventral incisions, and ligatures were placed to avoid the uterine veins and arteries. The animals were kept in individual cages in a climatically-controlled room at $22^{\circ} \mathrm{C}$, receiving artificial light from 06:00 to 18:00 h, and were given Purina Chow and water ad libitum. At 30 days after the surgery, the rabbits were randomly allocated into 6 groups ( 3 rabbits/group) and treated with 1 (Group 2) or 5 (Group 3) $\mu \mathrm{g}$ oestradiol-17/ $/ \mathrm{kg}$ body wt, $1 \mathrm{mg}$ progesterone/rabbit (Group 4), $1 \mathrm{mg}$ progesterone $/ \mathrm{kg}$ body wt (Group 5), or progesterone + oestradiol ( $1 \mathrm{mg}$ and $1 \mu \mathrm{g} / \mathrm{kg}$ body wt respectively) (Group 6). Control animals (Group 1) received vehicle only. The vehicle was $0 \cdot 2-$ $0.5 \mathrm{ml}$ corn oil and each steroid was given by separate intramuscular injection. Injections were given for 5 consecutive days. The rabbits were killed 2 days after the last injection. The uteri were removed, trimmed of fat, and weighed immediately. The endometria were scraped with a razor blade and then homogenized in ice-cold $40 \mathrm{~mm}$-Tris-HCl buffer $\mathrm{pH} 7 \cdot 4$, containing $0 \cdot 15 \mathrm{M}-\mathrm{NaCl}$ (Buffer A), using a Potter-Elvehjem glass homogenizer. The myometrium was cut into small pieces with scissors and homogenized in ice-cold Buffer A for $30 \mathrm{sec}$ in an Omni-mix Waring blender. Both preparations were centrifuged at $105000 \mathrm{~g}$ for $1 \mathrm{~h}$ (Beckman ultracentrifuge, SW65 rotor). The supernatants were collected and kept at $4^{\circ} \mathrm{C}$. These preparations will be referred to as 'soluble' fractions. The endometrium and myometrium sediments obtained after centrifugation were suspended and homogenized separately in $40 \mathrm{~mm}$-Tris- $\mathrm{HCl}$ buffer $\mathrm{pH} 7 \cdot 4$, containing $10 \mathrm{mM}-\mathrm{KCl}$,

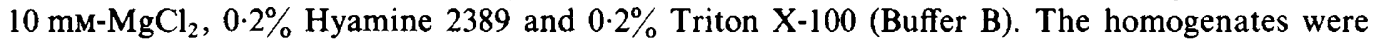
centrifuged at $23500 \mathrm{~g}$ for $30 \mathrm{~min}$. The supernatants contained the detergent-solubilized components (detergent extract). The sum of protein or enzyme activities in the soluble fraction and in the detergent extract constituted the total protein or enzyme activity. All preparations were dialysed against Buffer $\mathrm{A}$ and used for enzyme and protein determination.

Gonadotrophin treatment. Rabbits were superovulated by i.m. injection of 100 i.u. PMSG, followed $75 \mathrm{~h}$ later by an i.v. injection of 75 i.u. hCG. The control animals received the vehicle alone. A sample of blood was withdrawn from the heart ( $15 \mathrm{~h}$ after hCG) of each animal before it was killed by decapitation. The genital tracts were removed and immediately placed on ice. The uteri, oviducts, and ovaries were separated and quickly trimmed of extraneous tissue and fat. The wet weights were determined for each ovary, oviduct and uterine horn. The uterine and oviductal fluids were recovered by rapid flushing of the lumen with ice-cold Buffer A. Each rabbit tract was divided to give one ovary, one oviduct and one uterine horn in each of 2 groups. The endometrium, myometrium, ovary and the oviduct of one group were separately homogenized in Buffer A and centrifuged at $105000 \mathrm{~g}$ for $1 \mathrm{~h}$ ('soluble' fraction). Similarly, components in the other group were separately homogenized in Buffer B, and were centrifuged at $23500 \mathrm{~g}$ (detergent extract). The detergent extracts were dialysed against Buffer A.

Enzyme assays. In all the enzyme assays, the assay tube contained $0.2 \mathrm{ml}$ appropriate buffer, $0.2 \mathrm{ml}$ substrate and $0.1 \mathrm{ml}$ enzyme solution. The reaction mixture was incubated at $37^{\circ} \mathrm{C}$ for $5-120$ min depending on the activity of enzyme in specific preparations. The reaction was terminated by 
the addition of $2.5 \mathrm{ml} 1 \mathrm{~N}-\mathrm{NaOH}$. For arylsulphatase the amount of 4-nitrocatechol $(\varepsilon 515,12600$ lit mole ${ }^{-1} \mathrm{~cm}^{-1}$ ) produced was determined and converted to enzyme units. One unit of the enzyme is defined as the amount liberating $1 \mu \mathrm{mol} 4$-nitrocatechol per min. For other enzymes the amount of $p$-nitrophenol released was assessed by measuring absorbance at $405 \mathrm{~nm}$. The absorbance values were converted to enzyme activity units ( $\mu \mathrm{mol}$ nitrophenol liberated by the enzyme per min) by reference to the standard curve. Proper reagent and enzyme blanks were run and the absorbance corrected. The substrate and buffer used in each enzyme assay are given in Table 1.

Table 1. Substrate, buffer and $\mathrm{pH}$ conditions employed for the assay of lysosomal hydrolases

\begin{tabular}{|c|c|c|c|c|c|c|}
\hline Enzyme & EC no. & Substrate & $\begin{array}{c}\text { Buffer } \\
\text { (sodium) }\end{array}$ & $\begin{array}{c}\text { Fin } \\
\text { conc. (n }\end{array}$ & $\frac{1}{\text { M) of }}$ & $\begin{array}{c}\text { Buffer } \\
\text { pH }\end{array}$ \\
\hline Arylsulphatase & 3.1 .6 .1 & $\begin{array}{l}\text { 4-Nitrocatechol } \\
\text { sulphate }\end{array}$ & Acetate & 10 & 250 & $5 \cdot 5$ \\
\hline $\begin{array}{l}\text { Alkaline } \\
\text { phosphatase }\end{array}$ & 3.1 .3 .1 & $\begin{array}{l}p \text {-Nitrophenyl } \\
\text { phosphate }\end{array}$ & Carbonate & 20 & 20 & $10 \cdot 0$ \\
\hline $\begin{array}{l}\text { Acid } \\
\text { phosphatase }\end{array}$ & 3.1 .3 .2 & $\begin{array}{l}p \text {-Nitrophenyl } \\
\text { phosphate }\end{array}$ & Citrate & 20 & 20 & $4 \cdot 8$ \\
\hline$\beta$-Glucuronidase & 3.2 .1 .31 & $\begin{array}{l}p \text {-Nitrophenyl- } \\
\beta \text {-D-glucuronide }\end{array}$ & Acetate & $2 \cdot 4$ & 200 & $5 \cdot 0$ \\
\hline $\begin{array}{l}\beta \text { - } N \text {-acetyl- } \\
\text { hexosaminidase }\end{array}$ & 3.2 .1 .52 & $\begin{array}{l}p \text {-Nitrophenyl- } \\
\text { D-glucosaminide }\end{array}$ & Citrate & $2 \cdot 4$ & 20 & $4 \cdot 0$ \\
\hline$\alpha$-L-Fucosidase & 3.2 .1 .51 & $\begin{array}{c}p \text {-Nitrophenyl } \\
\alpha \text {-L-fucoside }\end{array}$ & Maleate & $2 \cdot 4$ & 40 & $6 \cdot 0$ \\
\hline$\beta$-Galactosidase & 3.2 .1 .23 & $\begin{array}{l}p \text {-Nitrophenyl- } \\
\beta \text {-D-galactoside }\end{array}$ & Acetate & $2 \cdot 4$ & 200 & $5 \cdot 0$ \\
\hline
\end{tabular}

Protein determination. Protein was measured by the method of Bradford (1976). If necessary, the absorbance was corrected for possible interference from Hyamine and Triton left in the samples after dialysis.

Treatment of data. Student's $t$ test was used to evaluate the data.

\section{Results}

The mean \pm s.d. uterine weight of 3 intact normal animals was $4 \cdot 3 \pm 0 \cdot 3 \mathrm{~g}$. Ovariectomy caused a significant reduction $(P<0 \cdot 01)$ in the uterine weight (Group 1, Table 2). Treatment with oestradiol and progesterone (Groups 2, 3 and 5) enhanced the uterine weight of ovariectomized animals $(P<0.01)$.

Endometrium. Based on $\mathrm{mg}$ protein and enzyme units per uterus (Table 2), the protein content and all enzymes increased significantly in Groups 2-6. However when data were expressed as units/g uterus, significant increases occurred only in Groups 4 and 5 . The activities of $\beta$-galactosidase and $\beta$ - $N$-acetylhexosaminidase were greater $(P<0.05)$ in Group 4 than in Group 5 animals. Although the total activities of some of the enzymes, such as a $\beta$-glucuronidase, $\beta$ - $N$-acetylhexosaminidase and $\alpha$-L-fucosidase were greater in Group 2 than in Group 3 animals, there were no significant differences in values expressed as units per $\mathrm{g}$ tissue. Values for Group 6 animals were intermediate between those of Groups 2 and 5. The activities of acid and alkaline phosphatases, $\alpha$ L-fucosidase and $\beta$-galactosidase in Group 6 animals were significantly increased $(P<0.05)$ over control values (Group 1). Since these enzymes also increased in Group 5 but not in Group 2, they can be regarded as progesterone-sensitive enzymes.

Myometrium. The changes in lysosomal enzymes induced by steroid hormones, especially by progesterone, were less pronounced than those induced in the endometrium (Table 3). Based on per 


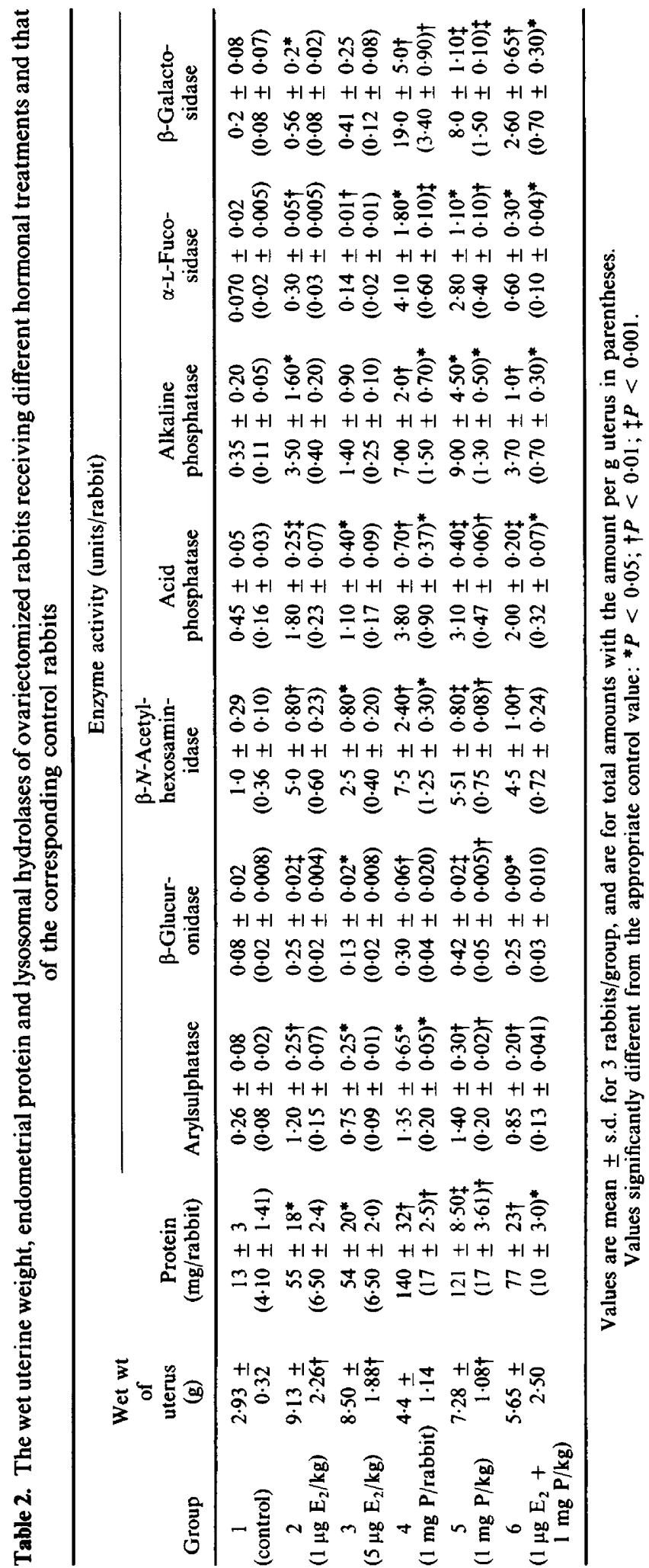




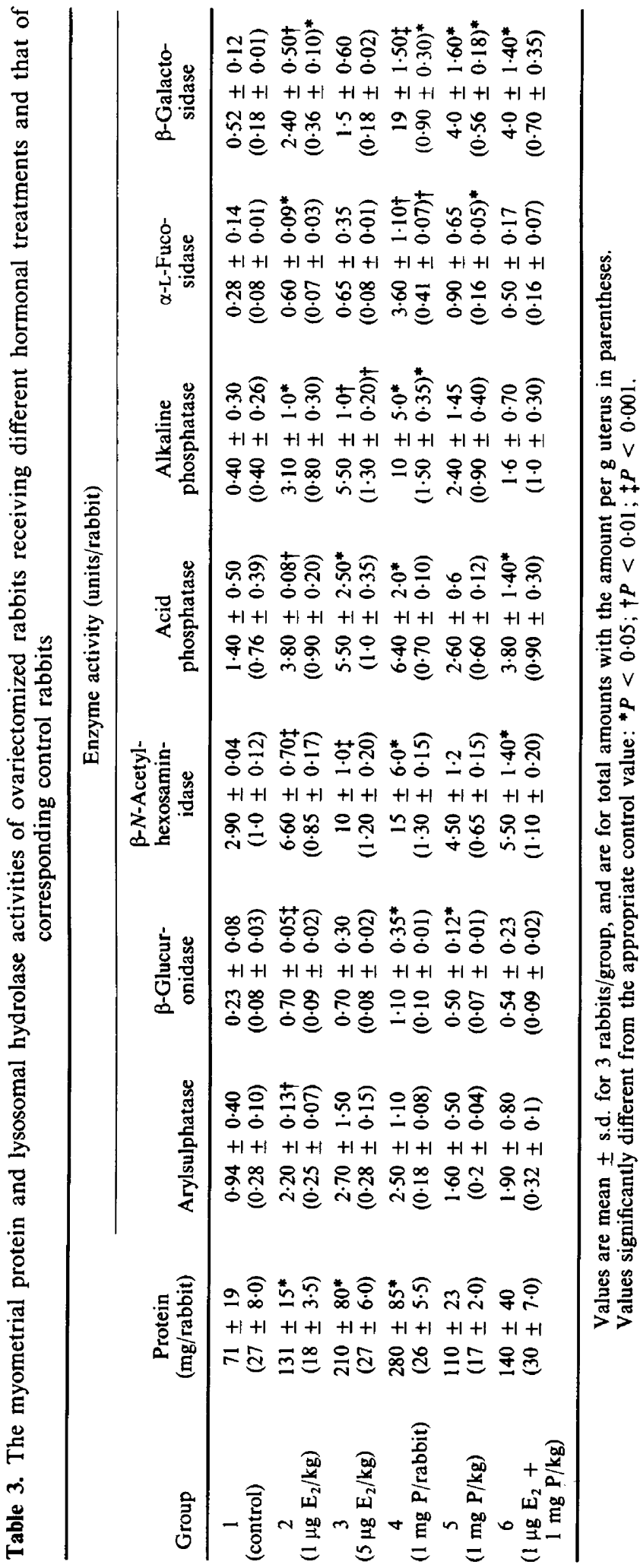


흐응 ó $\dot{0} \dot{0} \dot{0} \dot{0} \dot{0} \dot{0}$ $+1+1+1+1+1+1+1+1$

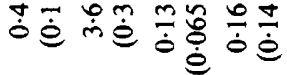

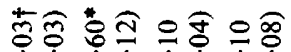
\& 这等

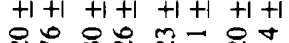

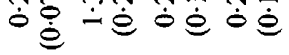

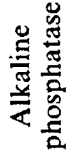

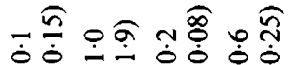
$\begin{array}{lll}0+1+1+1 & +1+1+1+1\end{array}$

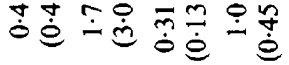

พลิ ó $\dot{0} \dot{0} \dot{0} \dot{0} 0 \dot{0}$ $+1+1+1+1+1+1+i+1$

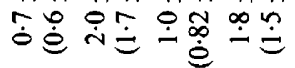

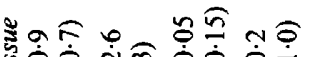

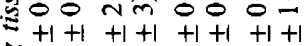

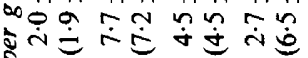
(2) ป ฐँ०

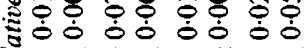
2 $+1+1+1+1+1+1+1+1$

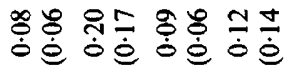

$n=\pi$ 约 $\dot{0} \dot{0} \dot{0} \dot{0} \dot{0} \dot{0} \dot{0} \dot{0}$ $+1+1+1+1+1+1+1+1$ 항융

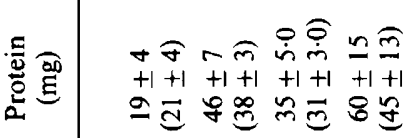

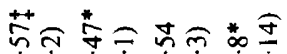

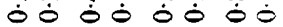
$+1+1+1+1+1+1+1+1$ 人்َ 30

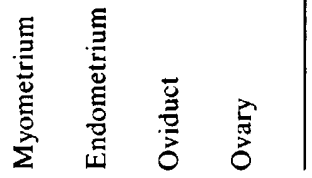

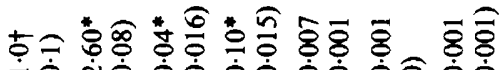

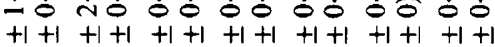

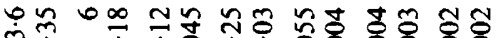

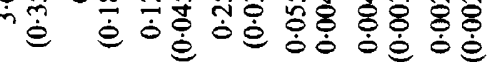

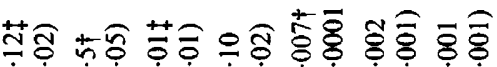
ó ó ó ó ó dó do dó $+1+1+1+1+1+1+1+1+1+1+1+1+1+1$

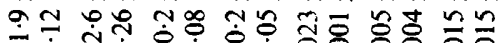
-

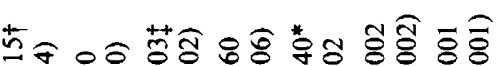

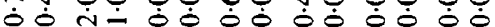
$+1+1+1+1+1+1+1+1+1+1+1+1+1+1$

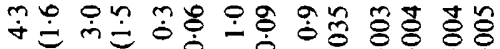

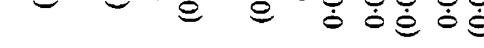

+ลำ

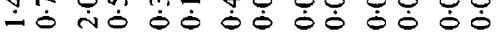
$+1+1+1+1+1+1+1+1+1+1+1+1+1+1$

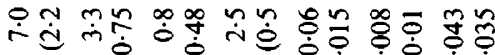

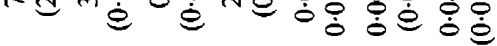

= $+1+1+1+1+1+1+1+1+1+1+1+1+1+1$ 帘 章.

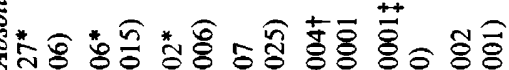
o $\dot{0} \dot{0} \dot{0} \dot{0} \dot{0} \dot{0} \dot{0} \dot{0} \dot{0}$ 0ं $\dot{0} \dot{0}$ $+1+1+1+1+1+1+1+1+1+1+1+1+1+1$

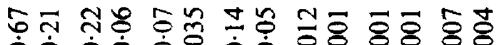

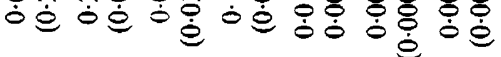

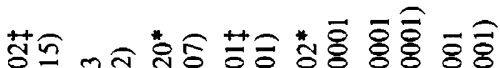
$\dot{0} \dot{0} \dot{-} \dot{0} \dot{0} \dot{0} \dot{0} \dot{0} \dot{0} \dot{0} \dot{0} \dot{0} \dot{0} \dot{0}$ $+1+1+1+1+1+1+1+1+1+1+1+1+1+1$

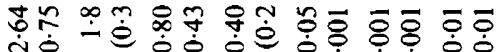

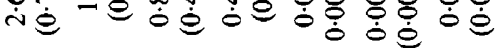

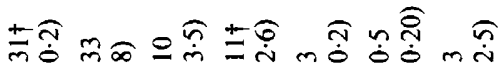
$+1+1+1+1+1+1+1+1+1+1+1+1+1+1$ 决

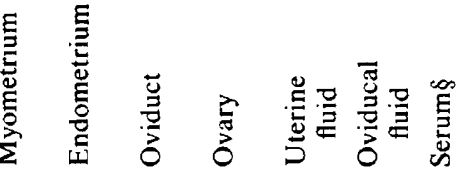


$\mathrm{g}$ uterus, there were significant differences from control values for $\beta$-galactosidase $(P<0 \cdot 05), \alpha$-Lfucosidase $(P<0.01)$ and alkaline phosphatase $(P<0.05)$ in Group 4 rabbits, $\beta$-galactosidase and $\alpha$-L-fucosidase $(P<0.05)$ in Group 5 rabbits and alkaline phosphatase $(P<0.01)$ for Group 3 rabbits.

Gonadotrophin treatment. The wet weight of myometrium, endometrium and ovaries increased significantly after PMSG-hCG treatment (Table 4). When protein and enzyme activities were expressed in terms of $\mathrm{mg}$ or units per $\mathrm{g}$ tissue, $\beta$-galactosidase, $\alpha$-L-fucosidase in the myometrium and endometrium, and glucuronidase and $\beta$-galactosidase in the oviduct showed significant increases over the control. Since the greater change in tissue weight might obscure the changes in enzymes, when expressed as unit/g tissue, the total amounts of enzyme per animal in various organs and fluids of PMSG-hCG treated rabbits are also presented in Table 4. In addition to the changes mentioned above most other enzymes differed significantly from control values. Due to the very low activities in the controls, all enzymes changed significantly in uterine fluid. With the exception of $\beta$ - $N$-acetylhexosaminidase, no significant differences between the levels of enzymes in the serum of hormonally treated and untreated animals were observed.

Solubility. Except for alkaline phosphatase and $\beta$-galactosidase the percentage of soluble enzymes in various organs of the steroid- or gonadotrophin-treated animals remained the same $(58 \pm 13 \%)$. The percentages of soluble alkaline phosphatase and $\beta$-galactosidase in the control myometrium were $35 \pm 3 \%$ and $52 \pm 4 \%$ respectively. There was a significant $(P<0.05-0.001)$ increase in the solubility of alkaline phosphatase in Groups 2, 3 and 6 and of $\beta$-galactosidase in Groups 2-6. The solubility of endometrial alkaline phosphatase in Group 4 animals differed $(P<$ 0.001 ) from that of the control animals.

\section{Discussion}

The role of hormones in the process of capacitation was first suggested by Chang (1958), when he reported that uterine capacitation was inhibited in pseudopregnant or progesterone-treated rabbits. Soupart (1967) observed that oestrogen at a concentration of $1 \mu \mathrm{g} / \mathrm{kg}$ body wt was required for maximum capacitation but that concentrations of $>4 \mu \mathrm{g} / \mathrm{kg}$ appeared to inhibit capacitation. Low levels of progestagens (0.5-1.5 mg, progesterone or 20 $\alpha$-dihydroprogesterone) also enhanced capacitation in ovariectomized oestrogen-treated rabbits, and higher levels of progestagen depressed capacitation (Plotka \& Williams, 1971). In the ovariectomized rabbit, $0.3 \mathrm{mg}$ progesterone/day was insufficient for implantation (Hafez \& Pincus, 1956), but injection of $1 \mathrm{mg}$ progesterone/day was sufficient for normal implantation (Pincus \& Werthessen, 1938; Kwun \& Emmens, 1975). Progesterone alone maintains pregnancy in the majority of ovariectomized adrenalectomized does, leaving any significant role for oestrogen in considerable doubt (Kwun \& Emmens, 1975).

The incorporation of $\left[{ }^{14} \mathrm{C}\right]$ glycine into proteins and ${ }^{35} \mathrm{~S}$ into the uterine mucopolysaccharides of ovariectomized rabbits reaches a maximum at 5-10 days during daily treatment with $1 \mu \mathrm{g}$ oestradiol $/ \mathrm{kg}$ (Henzl, Smith, Magoun \& Hill, 1968). The uterine acid and alkaline phosphatase contents also show striking changes at the same time in various uterine cells, as judged by cytochemical studies (Henzl et al., 1968). The hormonal regimen selected in this experiment was based on these observations.

The effects of progesterone and oestrogen on the wet weights of uteri observed in this study were similar to those found in other mammalian species (Hall, Stephenson, Mathias \& Brackett, 1977). Our results have also demonstrated that oestrogen and progesterone regulate the activities of lysosomal hydrolases in the endometria and myometria of ovariectomized rabbits. The changes in protein content of endometria and myometria in the present study confirm earlier studies showing that progesterone is responsible for regulating protein secretion in the rabbit uterus and that oestradiol causes only a slight increase in protein synthesis (Urzua, Stambaugh, Flickenger \& Mastroianni, 1970; Joshi \& Ebert, 1976). When oestrogen was administered simultaneously with progesterone, it appeared to have an inhibitory effect on the progesterone-induced synthesis of protein (Dunbar \& Daniel, 1979). 
These studies suggest that the proteins under hormonal regulation may participate in the processes of capacitation and/or implantation. For example, $1 \mu \mathrm{g}$ oestradiol $/ \mathrm{kg}$, which induces capacitation in ovariectomized rabbits (Soupart, 1967; Plotka \& Williams, 1971), also increased the level of lysosomal hydrolases (Table 2), while the concentrations of oestradiol that inhibit capacitation (Soupart, 1967) in the rabbit uterus inhibited the induction of lysosomal hydrolase. A progesterone treatment of $1 \mathrm{mg} / \mathrm{kg}$ body wt, which is sufficient for implantation and maintenance of pregnancy, effectively increased the levels of lysosomal hydrolases in the endometrium of the ovariectomized rabbits.

The antagonistic effects of progesterone and oestradiol on the production of lysosomal hydrolases are comparable to the inhibition of capacitation by progesterone (Chang, 1970; Plotka \& Williams, 1971) and the depression of implantation by oestrogen (Kwun \& Emmens, 1975). Some of the hormonally regulated enzymes may participate in preparing the embryo or uterus for implantation or assist in removing the zona pellucida from the embryo (Hoversland \& Weitlauf, 1981). Amongst other lytic enzymes $\beta$-galactosidase, $\alpha$-L-fucosidase and $\beta$ - $N$-acetylhexosaminidase, synthesized under the influence of progesterone (Tables 2 and 3), may be significant in these processes.

Steroids increase the rate of release of enzymes from lysosomes (deDuve et al., 1963) and change the permeability (Weissman, 1965) of the lysosomal membrane, as well as the subcellular distribution and concentration (Szego \& Seeler, 1973; Szego, 1974). The solubility of alkaline phosphatase increased in the myometrium of all rabbits treated with oestradiol (Groups 2, 3 and 6) and that of $\beta$ galactosidase increased in the myometrium of all steroid-treated rabbits (Groups 2-6). This may, therefore, indicate an increase in the rate of release of these enzymes as a result of the hormone treatment. $\beta$-Galactosidase and $\alpha-L$-fucosidase activities in the myometrium and endometrium increased in superovulated rabbits (Table 4), and these two enzymes were the most sensitive to progesterone administration in ovariectomized rabbits (Tables 2 and 3).

The augmentation of lysosomal hydrolases (Table 4) in the uterine fluid of superovulated rabbits may influence membranes of the embryo and endometrium or participate in sperm transport and capacitation. An increase in arylsulphatase activity in the uterine fluid of superovulated rabbits may be related to the metabolism of sulphated compounds in this species, the secretion of which is under hormonal control (Endo \& Yosizawa, 1973).

Since serum levels of lysosomal hydrolases do not change significantly with PMSG-hCG treatment, it seems unlikely that the effects occurring in the reproductive organs were generalized or caused by the systemic responses to the hormones.

This work was supported by a NIH Grant No. HD-14947-03. We thank Dr Sally O. Newell for assistance with ovariectomies and Miss Chris Berding for technical assistance.

\section{References}

Aitken, R.I. (1977) Changes in the protein content of mouse uterine flushings during normal pregnancy and delayed implantation and after ovariectomy and oestradiol administration. J. Reprod. Fert. 50, 29-36.

Allen, W.M. \& Corner, G.W. (1929) Physiology of the corpus luteum. III. Normal growth and implantation of embryos after very early ablation of the ovaries, under the influence of extracts of the corpus luteum. Am. J. Physiol. 88, 340-346.

Bradford, M.M. (1976) A rapid and sensitive method for the quantitation of microgram quantities of protein utilizing the principle of protein-dye binding. Analyt. Biochem. 72, 248-254.
Chang, M.C. (1958) Capacitation of rabbit spermatozoa in the uterus with special reference to the reproductive phase of the female. Endocrinology 63, 619-628.

Chang, M.C. (1970) Hormonal regulation of sperm capacitation. Adv. Biosci. 4, 13-35.

deDuve, C., Wattiaux, R. \& Wibo, M. (1963) Effect of fatsoluble compounds on lysosomes in vitro. In Proc. 1st Int. Pharmacological Meeting, pp. 97-116. Pergamon Press, New York.

Denker, H.W., Eng, L.A. \& Hamner, C.E. (1978) Studies on the early development and implantation in the cat. II. Implantation: proteinases. Anat. Embryol. 154, 39-54. 
Dimino, M.J. \& Elfont, E.A. (1980) The role of lysosomes in ovarian physiology. In The Biology of the Ovary, pp. 196-201. Eds P. M. Matta \& E. S. E. Hafez. Martinus Nijhoff Publisher, Boston.

Dimino, M.J., Malcom, S.E. \& Elfont, E.A. (1977) Changes in acid hydrolases activities of ovarian subcellular fractions of immature rats after gonadotropic treatment. Biol. Reprod. 17, 780-786.

Dott, H.M. (1973) Lysosomes and lysosomal enzymes in reproduction. Adv. Reprod. Physiol. 6, 213-220.

Dunbar, B.S. \& Daniel, J.C., Jr (1979) High molecular weight compounds of rabbit uterine fluids. Biol. $R e-$ prod. 21, 723-733.

Endo, M. \& Yoshizawa, Z. (1973) Hormonal effects on glycoproteins and glycosaminoglycans in rabbit uteri. Arch. Biochem. Biophys. 156, 397-403.

Findlay, J.K., Ackland, N., Burton, R.D., Davis, A.J., Walker, F.M.M., Walters, D.E. \& Heap, R.B. (1981) Protein, prostaglandin and steroid synthesis in caruncular and intercaruncular endometrium of sheep before implantation. J. Reprod. Fert. 62, 361-377.

Gwatkin, R.B.L. \& Hutchinson, C.F. (1971) Capacitation of hamster spermatozoa by $\beta$-glucuronidase. Nature, Lond. 229, 343-344.

Hafez, E.S.E. \& Pincus, G. (1956) Hormonal requirements for implantation in the rabbit. Proc. Soc. exp. Biol. Med. 91, 531-534.

Hall, J.L., Stephenson, R.B., Mathias, C.A. \& Brackett, B.G. (1977) Hormonal dependence of cyclic patterns in hamster uterine fluid proteins. Biol. Reprod. 17, $738-744$.

Hall, K. \& Khaligh, H.S. (1968) The action of ovarian steroids and relaxin on glycogen and some enzyme activities in the uterus of the hamster. J. Endocr. 40, 353-362.

Hamner, C.E., Jones, J.P. \& Sojka, N.J. (1968) Influence of the hormonal state of the female on the fertilizing capacity of rabbit spermatozoa. Fert. Steril. 19, 137143.

Henzl, M.R., Smith, R.E., Magoun, R.E. \& Hill, R. (1968) The influence of oestrogens on rabbit endometrium. Fert. Steril. 19, 914-935.

Henzl, M.R., Smith, R.E., Boost, G. \& Tyler, E.T. (1972) Lysosomal concept of menstrual bleeding in human. J. clin. Endocr. Metab. 34, 860-875.

Hoversland, R.C. \& Weitlauf, H.M. (1981) Lysis of the zona pellucida and attachment of embryos to the uterine epithelium in ovariectomized mice treated with oestradiol-17$\beta$ and progesterone. J. Reprod. Fert. 62, 11!-116.

Jelinek, J. \& Jelinkova, M. (1975) Changes in the endometrial enzymes of rats during the estrous cycle and early pregnancy. Acta endocr., Copenh., Suppl. 199, 273, Abstr.

Joshi, S.G. \& Ebert, K.M. (1976) Effects of progesterone on labelling of soluble proteins and glycoproteins in rabbit endometrium. Fert. Steril. 27, 730-739.
Kaye, A.M. \& Reiss, N. (1980) The uterine "estrogen induced protein" (IP): purification, distribution and possible function. In Steroid Induced Proteins, pp. 320. Ed. M. Beato. Biomedical Press, Elsevier/NorthHolland, Amsterdam.

Kwun, J.K. \& Emmens, C.W. (1975) Further observation on hormonal support of pregnancy in the ovariectomized rabbit. Aust. J. biol. Sci. 28, 291-299.

Laidler, K.J. \& Krupka, R.M. (1961) Enzyme mechanisms in relation to the mode of action of steroid hormones. In Mechanisms of Action of Steroid Hormones, p. 235. Pergamon Press, New York.

McRorie, R.A. \& Williams, W.L. (1974) Biochemistry of mammalian fertilization. Ann. Rev. Biochem. 43, 777803.

Moulton, B.C., Koenig, B.B. \& Borkan, S.C. (1978) Uterine lysosomal enzyme activity during ovum implantation and early decidualization. Biol. Reprod. 19, 167170.

Murdoch, R.N., Kay, D.J. \& Cross, M. (1978) Activity and subcellular distribution of mouse uterine alkaline phosphatase during pregnancy and pseudopregnancy. J. Reprod. Fert. 54, 293-300.

Pincus, G. \& Werthessen, N.T. (1938) The maintenance of embryo life in ovariectomized rabbits. Am. J. Physiol. 124, 484-490.

Plotka, E.D. \& Williams, W.L. (1971) Hormones and sperm capacitation in rabbits. Proc. Soc. exp. Biol. Med. 136, 934-936.

Rosado, A., Mercado, E. \& Gallegor, A.J. (1977) Subcellular distribution of lysosomal enzymes in the human endometrium. I. Normal menstrual cycle. Contraception 16, 287-298.

Shalgi, R., Kaplan, R. \& Kraicer, P.F. (1977) Proteins of follicular, bursal and ampullar fluids of rats. Biol. Reprod. 17, 333-338.

Sloane, B.F. (1980) Lysosomal apparatus in uterine muscle: effects of estrogen and of ovariectomy. Biol. Reprod. 23, 867-876.

Soupart, P. (1967) Studies on the hormonal control of rabbit sperm capacitation. J. Reprod. Fert., Suppl. 2 , 49-63.

Surani, M.A.H. (1977) Qualitative and quantitative examination of the proteins of rat uterine luminal fluid during pro-oestrus and pregnancy and comparison with those of serum. J. Reprod. Fert. 50, 281-287.

Szego, C.M. (1974) The lysosome as mediator of hormone action. Recent Prog. Horm. Res. 30, 171-233.

Szego, C.M. \& Seeler, B.J. (1973) Hormone-induced activation of target-specific lysosomes: acute translocation to the nucleus after administration of gonadal hormones in vivo. J. Endocr. 56, 347-360.

Urzua, M.A., Stambaugh, R., Flickenger, G. \& Mastroianni, L. (1970) Uterine and oviduct fluid protein patterns in the rabbit before and after ovulation. Fert. Steril. 21, 860-865.

Weissman, G. (1965) Lysosomes. New Eng. J. Med. 273, 1084-1090. 